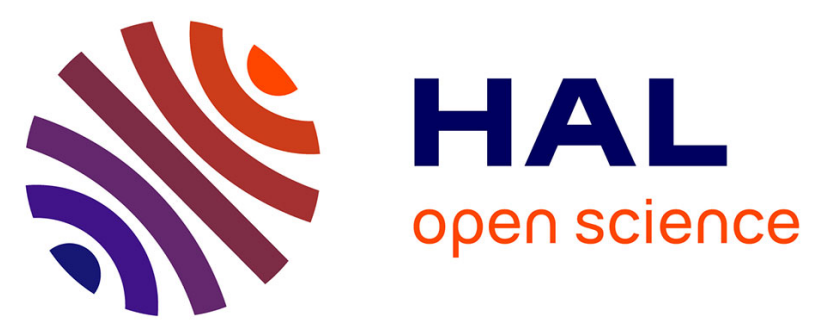

\title{
Measuring the Effects of Urban Heat Island Mitigation Techniques in the Field: Application to the Case of Pavement-Watering in Paris
}

Martin Hendel, Pierre Gutierrez, Morgane Colombert, Youssef Yd Diab, Laurent Royon

\section{To cite this version:}

Martin Hendel, Pierre Gutierrez, Morgane Colombert, Youssef Yd Diab, Laurent Royon. Measuring the Effects of Urban Heat Island Mitigation Techniques in the Field: Application to the Case of Pavement-Watering in Paris. Urban Climate, 2016, 10.1016/j.uclim.2016.02.003 . hal-01113917v4

\section{HAL Id: hal-01113917 \\ https://hal.science/hal-01113917v4}

Submitted on 2 Mar 2016

HAL is a multi-disciplinary open access archive for the deposit and dissemination of scientific research documents, whether they are published or not. The documents may come from teaching and research institutions in France or abroad, or from public or private research centers.
L'archive ouverte pluridisciplinaire HAL, est destinée au dépôt et à la diffusion de documents scientifiques de niveau recherche, publiés ou non, émanant des établissements d'enseignement et de recherche français ou étrangers, des laboratoires publics ou privés. 


\section{Measuring the Effects of Urban Heat Island Mitigation Techniques in the Field: Application to the Case of Pavement-Watering in Paris}

\section{Martin HENDEL ${ }^{1 *}$, Pierre GUTIERREZ ${ }^{2}$, Morgane COLOMBERT ${ }^{3}$, Youssef DIAB ${ }^{3}$, Laurent ROYON ${ }^{4}$}

${ }^{1}$ Univ Paris Diderot, Sorbonne Paris Cité, LIED, UMR 8236, CNRS, F-75013, Paris, France

2Dataiku, Data Science Team, F-75001, Paris, France

${ }^{3}$ Université Paris-Est, Lab’Urba, EA 3482, EIVP, F-75019, Paris, France

${ }^{4}$ Univ Paris Diderot, Sorbonne Paris Cité, MSC, UMR 7057, CNRS, F-75013, Paris, France

*corresponding author: martin.hendel@univ-paris-diderot.fr

\section{ABSTRACT}

Urban heat island (UHI) countermeasures are of growing interest for cities. Field studies of their micro-climatic effects are scarce, yet are essential to properly evaluate their effectiveness and that of anti-UHI policies. The standard approach to determining their micro-climatic effects is to study the difference in measurements made at case and control stations. However, measurements conducted during a pavement-watering experiment in Paris, France reveal that this method mistakes preexisting differences for pavement-watering effects. An alternative approach based on a twosample t-test was therefore developed and tested with the pavement-watering field trial as a case study. The proposed method proved able to determine the effects of pavement-watering, without misinterpreting preexisting differences. In the process of the case study, watering was found to reduce maximum daily heat stress, while having smaller statistically significant UHI-reducing effects. The greatest effects were reached during the day for all parameters with maximum reductions of $0.79^{\circ} \mathrm{C}, 1.76^{\circ} \mathrm{C}$ and $1.03^{\circ} \mathrm{C}$ for air, mean radiant and UTCI-equivalent temperatures and a $4.1 \%$ increase in relative humidity, while UHI-mitigation reached up to $-0.22^{\circ} \mathrm{C}$. The methodology developed is not specific to pavement-watering and recommendations for its improvement and its application to the field-evaluation of other UHI countermeasures are made.

\section{Introduction}

Countermeasures to the urban heat island (UHI) effect are of growing interest to decision makers. Certain measures have been encouraged or made mandatory for new buildings through local legislation or regulation, such as California's Title 24 in the case of cool roofs [1]. Such policies are supported by the growing scientific literature on the topic of UHI countermeasures, yet proper evaluation tools are required in order to analyze their effectiveness in the field.

To date, cool materials, which can be reflective, permeable or covered with low vegetation such as grass, have been thoroughly studied in the lab or on small-scale prototypes [2]-[7]. Results indicate that surface temperatures are significantly reduced compared to standard materials. This in turn is expected to result in lower contributions to urban heating. Equivalent work on green spaces has mostly focused on existing parks [8], [9]. Findings indicate cooling of up to a few degrees through the combined effects of evapotranspiration and shading. However, field evaluations and monitoring of large-scale uses of cool materials or new urban green spaces remain scarce [10], [11], with most large-scale micro-climatic effects being studied with the help of computer simulations [12]-[14].

Pavement-watering stands out as an exception and has been studied in the field via several independent studies. These may be useful in providing appropriate field analysis methods for other UHI countermeasures. Japan began work in the 1990's with the use of preexisting pavementwatering installations in Nagaoka City or block-scale demonstrators in Tokyo [15]-[18]. More 
recently, the city services of Paris or Lyons in France have conducted field studies with the use of cleaning trucks or permanent watering infrastructure prototypes [19], [20]. In all of these cases, the analysis is based on a direct comparison between case and control measurements, the observed interstation difference being interpreted as the effect of pavement-watering.

Unfortunately, this analysis method is flawed. Indeed, it tacitly assumes that measurements at two different stations are equal in normal conditions, i.e. prior to UHI countermeasure implementation. Given the inherent complexity of urban environments, this is highly unlikely. Since direct case-control station comparisons do not account for preexisting differences between measurement stations, the method may misinterpret them as the studied countermeasure's effect.

This paper proposes an alternative statistical analysis method based on a two-sample t-test of differences. A pavement-watering experiment will be used as a test application of the method. This experiment was conducted in Paris, France during the summers of 2013 and 2014 and has been previously studied by the authors to describe the thermal effects of pavement-watering and to optimize the watering method [21]-[23]. In addition to providing practical feedback on the proposed analysis method, further light will be shed on the effects of pavement-watering on micro-climatic parameters and pedestrian thermal comfort as well.

\section{Pavement-watering materials and methods}

Most previous work has studied the effects of watering only pavement surfaces, leaving the sidewalks untreated [15]-[18], [20]. Yet, pedestrians mostly use sidewalks and should therefore benefit significantly from sidewalk watering in addition to pavement watering. We therefore set out to test both methods at the two different sites.

\subsection{Site selection}

Two sites in Paris, France were investigated over the summers of 2013 and 2014. Local micro-climatic data was measured on the rue du Louvre, located on the border of the $1^{\text {st }}$ and $2^{\text {nd }}$ Arrondissements, and in the $20^{\text {th }}$ Arrondissement. Both sites have a canyon aspect ratio approximately equal to one and will be respectively referred to as the Louvre and Belleville sites hereafter. Watered and control weather station positions are illustrated in Figure 1. Two twin weather stations were positioned for each site, each pair measuring identical parameters.

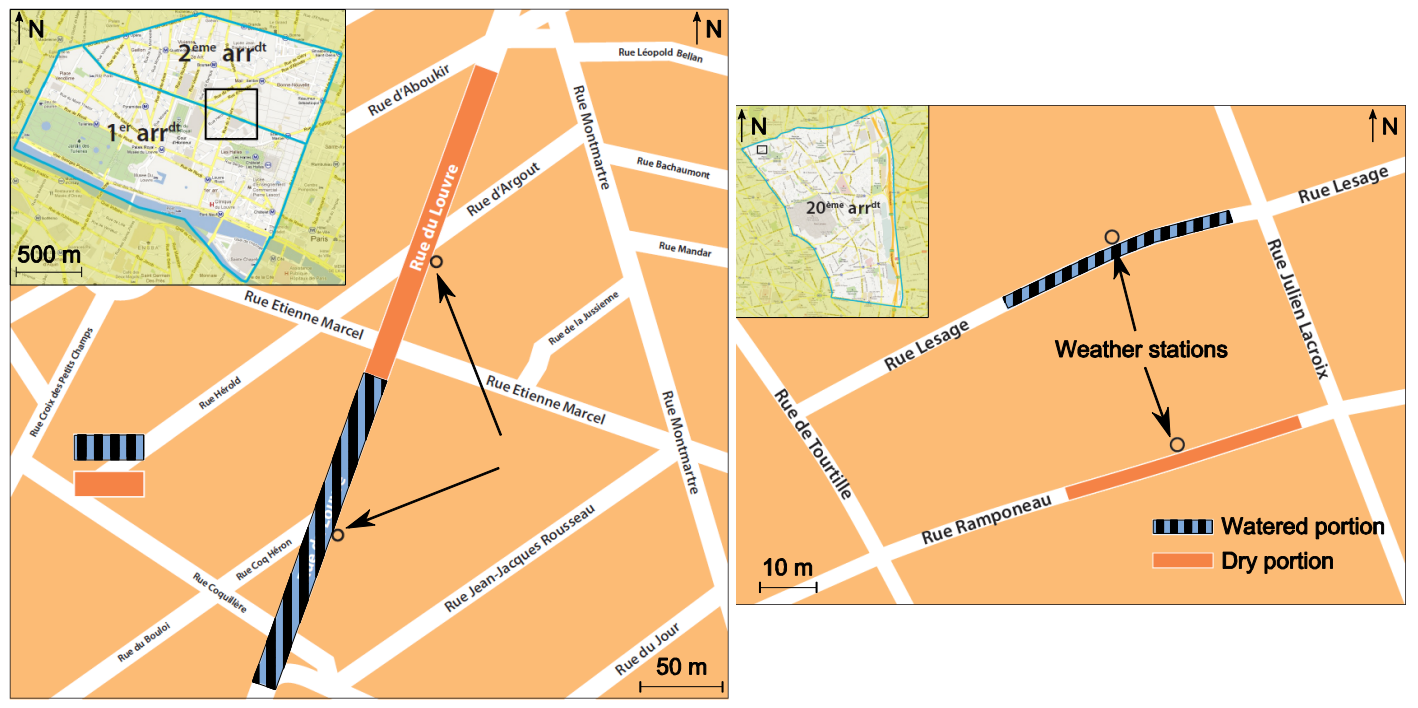

Figure 1: Map of weather station positions at the Louvre (left, from [21]) and Belleville (right) sites 
Both sites were chosen for practical reasons related to the watering method such as available watering infrastructure, water pressure, traffic considerations, etc. (see section 2.4). However, other factors were also taken into account in order to filter out other influences and facilitate the detection of the pavement-watering effect. Each pair was therefore selected following strict criteria. These included a minimum distance between stations (10 times street width at least), minimal immediate presence of vegetation, identical street orientations, canyon aspect ratios and street widths. Pairs were also chosen so that the urban materials around them, e.g. roads or building façades, were as similar as possible. Road traffic, surrounding parks and vegetation, station shading and topography were also controlled for.

Louvre stations are positioned approximately 200 meters apart in the same street, while they were positioned in two parallel streets, rue Lesage and rue Ramponeau, at the Belleville site. In terms of road materials, impervious asphalt concrete approximately $16 \mathrm{~cm}$ deep is laid on a 16-cm cementtreated base at the Louvre stations. At the Belleville stations, different cobblestones are used at the watered and control sites, with sandstone pavers at the case and granite pavers at the control.

Rue du Louvre, rue Lesage and rue Ramponeau have an aspect ratio approximately equal to one $(\mathrm{H} / \mathrm{W}=1)$. Rue du Louvre has a N-NE - S-SW orientation, while at Belleville both streets have an E-NE - W-SW orientation.

As an indication of the resulting match between stations, Figure 2 compares solar irradiance measurements $4 \mathrm{~m}$ a.g.l. at the case and control stations for Louvre and Belleville on July 14 ${ }^{\text {th }}, 2013$. Details on the measurement method can be found in previous work conducted by the authors [21].
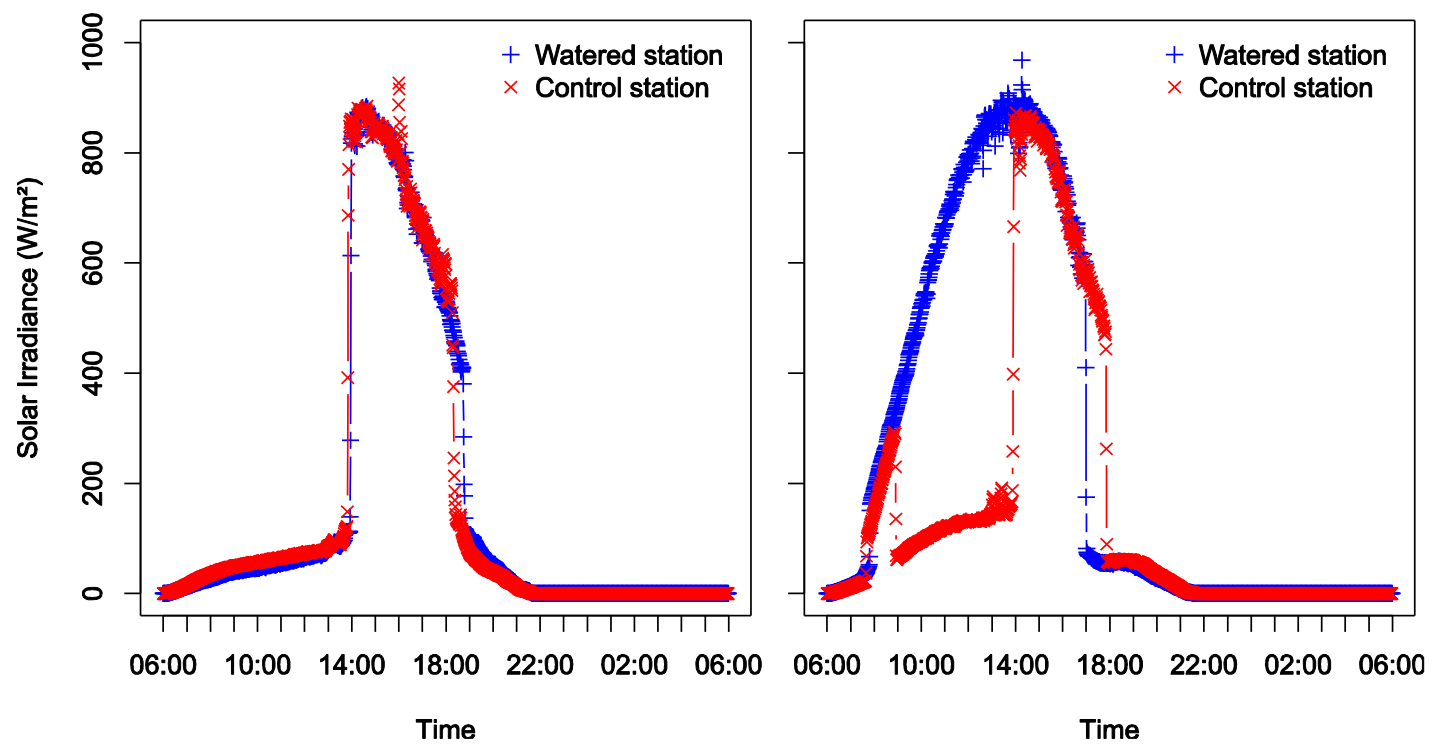

Figure 2: Solar irradiance at Louvre (left) and Belleville (right) on July 14 ${ }^{\text {th }}, 2013$.

While solar irradiance measurements at the Louvre stations are highly consistent with each other, significant differences are visible between the Belleville stations, occurring from 9 am to $2 \mathrm{pm}$ and from $5 \mathrm{pm}$ to $6 \mathrm{pm}$. This is due to slight differences in building heights and street orientations. Overall, the match between stations is much better for Louvre than for Belleville in terms of insolation. 


\subsection{Instruments}

Weather station design is presented in Figure 3 for rue du Louvre. Instruments within pedestrian reach were protected behind a cylindrical white-painted steel cage, reaching 2 meters high at the Louvre site and 3 meters at the Belleville site. Photographs are provided in Figure 4.

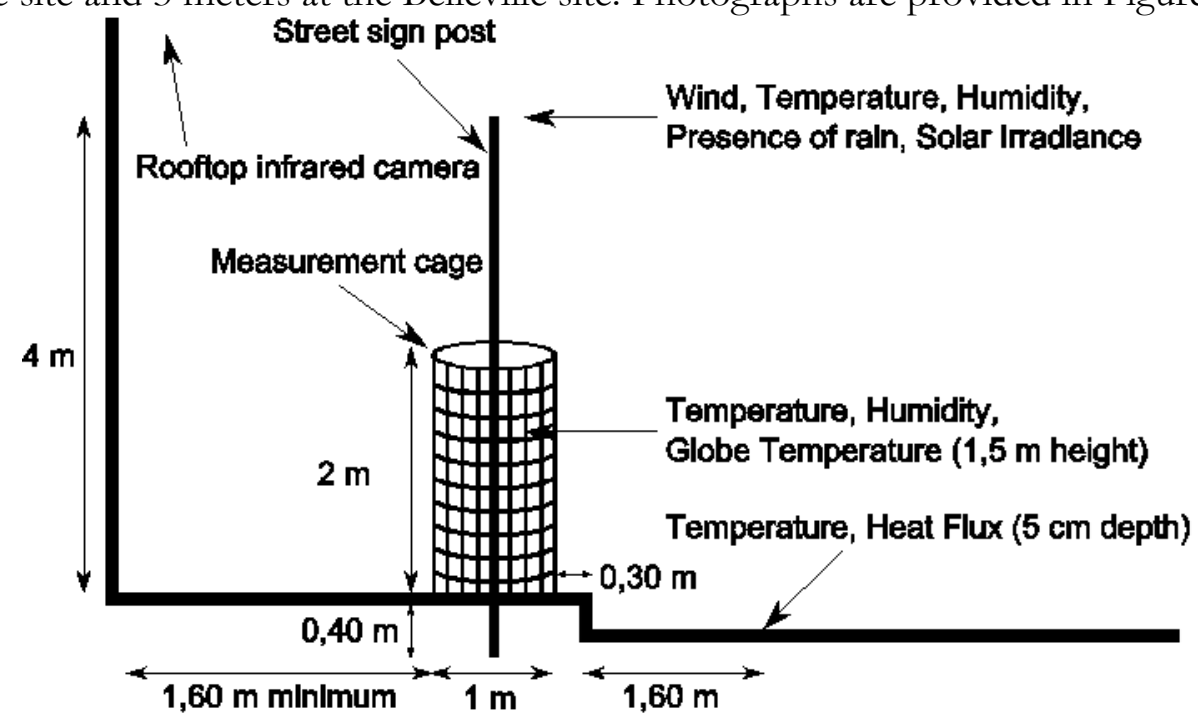

Figure 3: Weather station design and instrumentation (rue du Louvre)
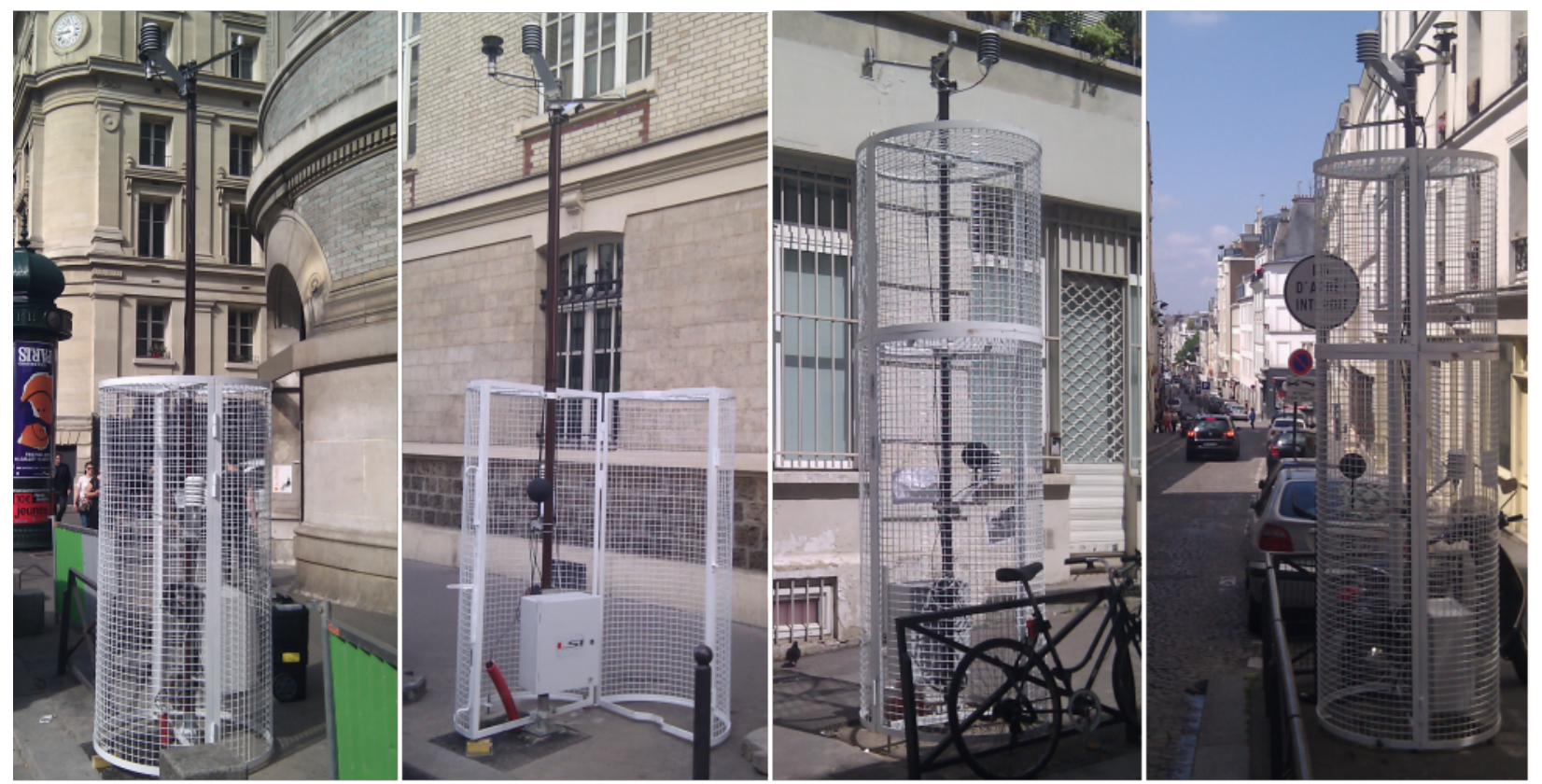

Figure 4: Photographs of watered and control weather stations in situ, from left to right : watered and control Louvre stations, watered and control Belleville stations.

Black globe temperature $\left(T_{g}\right)$, air temperature $\left(T_{a}\right)$ and wind speed $(v)$ measurements from the weather station were used to estimate mean radiant temperature (MRT) following the ASHRAE method [24]. Table 1 summarizes the instruments used for this analysis as well as their measurement height and accuracy. Prior to the investigation, wind sensors and black globe thermometers were calibrated according to relevant standards [25], [26], while the thermo-hygrometers were compared 
with a calibrated reference sensor. All measurements were recorded continuously every minute and are presented in local daylight savings time $(\mathrm{UTC}+2)$.

Table 1: Instrument type, measurement height above ground level and accuracy

\begin{tabular}{|c|c|c|c|c|c|c|}
\hline Parameter & Instrument & Model & Manufacturer & Height & Symbol & Uncertainty \\
\hline $\begin{array}{l}\text { Air } \\
\text { temperature }\end{array}$ & Sheltered Pt100 & \multirow{2}{*}{$\begin{array}{l}\text { DMA } \\
672.1\end{array}$} & \multirow{3}{*}{ LSI LASTEM } & \multirow{2}{*}{$\begin{array}{c}1.5 \mathrm{~m} \\
\text { and } \\
4 \mathrm{~m}\end{array}$} & $T_{a}$ & $0.10^{\circ} \mathrm{C}$ \\
\hline $\begin{array}{l}\text { Relative } \\
\text { humidity }\end{array}$ & $\begin{array}{l}\text { Sheltered capacitive } \\
\text { hygrometer }\end{array}$ & & & & RH & $1.5 \% \mathrm{RH}$ \\
\hline $\begin{array}{l}\text { Globe } \\
\text { temperature }\end{array}$ & $\begin{array}{l}\text { Black Globe } \\
\text { Thermometer }\end{array}$ & $\begin{array}{c}\text { EST } \\
131 \\
\end{array}$ & & $1.5 \mathrm{~m}$ & $T_{g}$ & $0.15^{\circ} \mathrm{C}$ \\
\hline Wind speed & $\begin{array}{l}\text { 2-axis ultrasonic } \\
\text { anemometer }\end{array}$ & $\begin{array}{l}\text { Wind } \\
\text { Sonic }\end{array}$ & Gill Instruments & $4 \mathrm{~m}$ & $v$ & $2 \%$ \\
\hline
\end{tabular}

\subsection{Thermal comfort and UHI-mitigation potential indexes}

Universal Thermal Climate Index (UTCI) was calculated from these measurements for each station to estimate pedestrian thermal comfort [27]. UTCI was developed by international experts from Commission 6 of the International Society of Biometeorology (ISB) and European COST Action 730 from the year 2000 to 2009. It is based on a special version of the multi-node Fiala thermophysiological model. Air temperature, humidity, wind speed and MRT are used as well as assumptions on the metabolic activity and clothing of pedestrians to calculate an equivalent air temperature for reference conditions.

We fast-calculated UTCI equivalent temperature with Peter Bröde's 2009 FORTRAN script which we adapted for use with the $\mathrm{R}$ software environment. The source code is freely available online [28].

The UHI-mitigation potential of pavement-watering will be evaluated as the change in average air temperature between 3 am and 6 am on the day after watering both $1.5 \mathrm{~m}$ and $4 \mathrm{~m}$ above ground level (a.g.l.). This criterion is very similar to that used by Météo-France and CSTB [14].

Inaccuracies are introduced into both MRT and UTCI by the use of 4-m wind speed rather than 1.5-m and 10-m wind speeds, respectively. This is assumed to result in an overestimation of wind speed, which should result in an underestimation of MRT and UTCI given the considered weather conditions. In addition, the cage is expected affect measurements as well. While air temperature and humidity are not expected to be influenced by it, globe temperature measurements are expected to be underestimated due to partial instrument shading. These error sources and their impact have not been investigated.

\subsection{Watering method}

The watering method applied to the Louvre site is that described by Hendel et al. [21]. Namely, watering was started if certain weather conditions were met based on Météo-France's threeday forecast. These as well as those for heat-wave warnings are presented in Table 2. BMI $I_{\text {ax }}$ and $B M I_{M i n}$ refer to the 3-day mean of maximum $\left(T_{x}\right)$ and minimum $\left(T_{n}\right)$ air temperatures.

On rue du Louvre, cleaning trucks were used to sprinkle approximately $1 \mathrm{~mm}$ every hour from 6:30 am to 11:30 am and every 30 minutes from $2 \mathrm{pm}$ until 6:30 pm on the pavement, assisted 
by a manual operator to sprinkle the same amount on the sidewalk. Both watered and dry portions of the street are approximately $180 \mathrm{~m}$ long and $20 \mathrm{~m}$ wide.

Table 2: Weather conditions required for pavement-watering and heat wave warnings [21]

\begin{tabular}{|l|c|c|}
\hline Parameter & Pavement-watering & Heat-wave warning level \\
\hline$T_{n}$ & $B M I_{\text {Min }} \geq 16^{\circ} \mathrm{C}$ & $\geq 21^{\circ} \mathrm{C}$ for three consecutive days \\
\hline$T_{x}$ & $B M I_{M a x} \geq 25^{\circ} \mathrm{C}$ & $\geq 31^{\circ} \mathrm{C}$ for three consecutive days \\
\hline$v$ & $\leq 10 \mathrm{~km} / \mathrm{h}$ & - \\
\hline Sky conditions & Sunny (less than 2 oktas cloud cover) & - \\
\hline
\end{tabular}

At Belleville, a removable $40 \mathrm{~m}$ watering pipe was laid along the gutter to water the cobblestone pavement on rue Lesage continuously from 7 am to $7 \mathrm{pm}$ across its 4 meter width. Water use at the Belleville site was approximately $25 \mathrm{~mm} / \mathrm{h}$. The watering process is illustrated for both sites in Figure 5.

In terms of the watered-to-total area ratio, rue du Louvre was 100\% watered, while rue Lesage was approximately $33 \%$ watered.

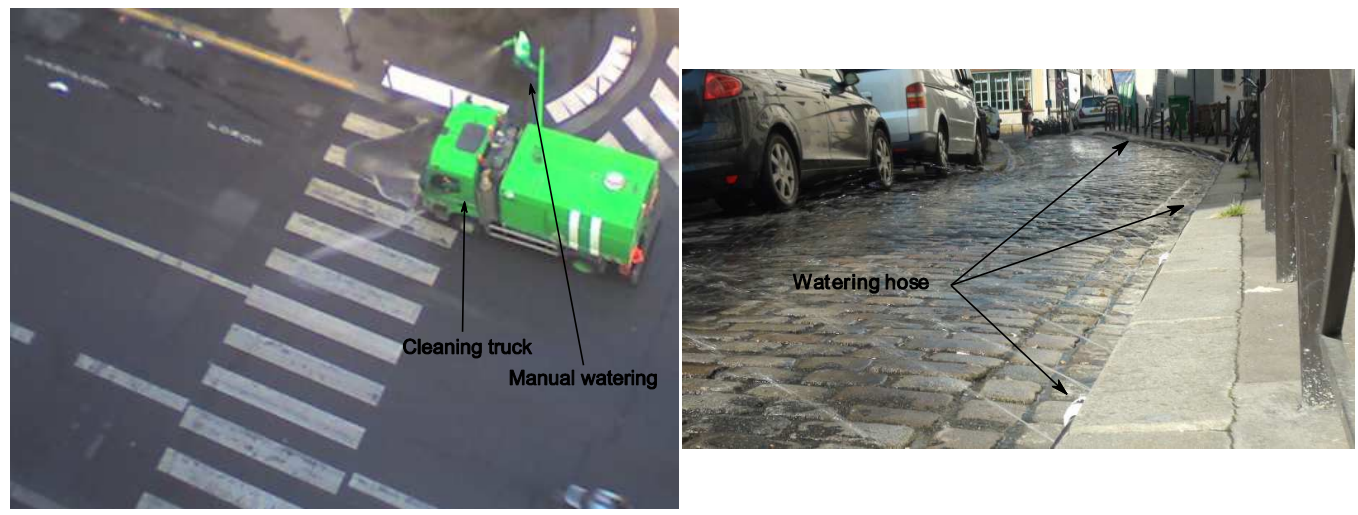

Figure 5: Watering on rue du Louvre (left, from [22]) and rue Lesage (right)

Water used for this experiment was supplied by the city's 1,600-km non-potable water network, principally sourced from the Ourcq Canal. Although water temperature was not measured, its typical summertime range is $20^{\circ}-25^{\circ} \mathrm{C}$.

\subsection{Heat transfer analysis}

Figure 6, adapted from Hendel et al. [21], shows a diagram of the surface heat exchanges at the pavement surface. 


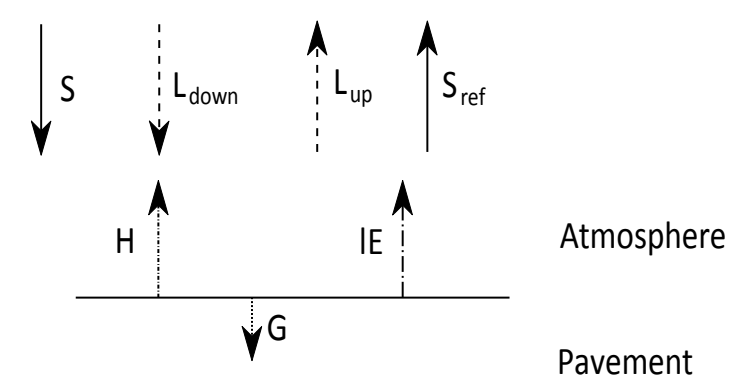

Figure 6: Diagram of pavement heat budget at surface

The energy balance of the pavement surface is governed by the following equations taken from Hendel et al. [21] in dry and wet conditions:

$$
\begin{aligned}
& R_{n}=S+L_{d o w n}-L_{\text {up }}-S_{\text {ref }} \\
& R_{n}^{d r y}=H^{d r y}+G^{d r y} \\
& R_{n}^{w e t}=H^{w e t}+G^{w e t}+\Phi \\
& \Phi=l E+c \rho \frac{V_{s}}{t_{0}}\left(T_{S}^{w e t}-T_{W}\right)
\end{aligned}
$$

$R_{n}$ is the net downward radiation received by the pavement surface and is the sum of the downward solar irradiance (shortwave radiation) $S$, downward longwave radiation $L_{\text {down }}$ and upward longwave radiation $L_{u p}$ and reflected shortwave radiation $S_{r e} ; H$ is the upward atmospheric sensible heat flux; $G$ is the downward pavement heat flux at the surface; $l$ is the latent heat of vaporization for water; $E$ is the evaporation rate; $c$ is the specific heat of water; is the density of water; $V_{s}$ is the water volume dispersed per unit surface area $\left(1 \mathrm{~L} / \mathrm{m}^{2}\right)$; $t_{0}$ is the water cycle period in seconds; $T_{S}$ is the surface temperature of the pavement; $T_{W}$ is the water temperature; designates the pavementwatering cooling flux.

The cooling flux created by pavement-watering is expected to affect micro-climatic conditions, including air and mean radiant temperature reductions and relative humidity increases. Firstly, lower pavement surface temperatures will result in lower convective heat flux, which in turn should cause air temperature reductions. Secondly, relative humidity is expected to increase as a result of water evaporation. Finally, increased shortwave absorptivity as a result of surface wetting [29] and lower surface temperatures are expected to reduce upward short- and longwave radiation from the pavement, resulting in a reduction of mean radiant temperature. These effects will be commensurate to the size of the watered zone.

In terms of thermal comfort, the increase in relative humidity has the opposite effect of the reductions in air and mean radiant temperature. Therefore watering may in fact result in greater thermal discomfort for pedestrians if the humidity increase is too great in comparison to the other expected cooling effects. It is therefore uncertain whether the combination of these effects will improve or degrade pedestrian thermal comfort.

\subsection{Data formatting}

Unless otherwise specified, the analyses focus on the difference between case and control stations, referred to as the interstation difference and calculated in the following fashion: $y_{\text {difference }}=y_{\text {watered }}-y_{\text {control }}$. Negative values therefore indicate that the watered station parameter is lower than that of the control station, and vice versa. 
For better comparability between days with and without watering, the discussed daily time series will begin at 6 am and end at 5:59 am the following day. Thus, data from July $8^{\text {th }}$ refers to data collected between July $8^{\text {th }}$ at 6 am and July $9^{\text {th }}$ at 5:59 am.

Since pavement-watering is being considered to help reduce thermal heat stress during heat waves, only days of Pasquill atmospheric stability class A or A-B [30] will be considered. Indeed, this condition requires insolation to be high (i.e. clear or very low cloud cover) and wind speeds to be low (less than $3 \mathrm{~m} / \mathrm{s}$ ). Hereafter, days of Pasquill class A or A-B without watering will be referred to as "reference days", while those with watering will be called "watered days".

For the upcoming analyses, the one-minute data series are smoothed with a ten-minute moving average.

\section{Analysis method}

As described in the Introduction, the standard method used in previous work on pavementwatering is to interpret its effect as the interstation difference between two stations or areas: one experimental, i.e. watered, and one control, i.e. unwatered [15]-[20]. In doing so, the hypothesis is implicitly made that under normal conditions without pavement-watering, the interstation difference is constant and equal to zero. This assumption is unlikely in dense urban environments.

\subsection{Confrontation of standard approach with field measurements}

Our observations immediately confirm that the initial hypothesis is unfounded, even with stations paired as strictly as ours and with highly comparable weather conditions. This is clearly visible in Figure 7 for the Louvre site between July $2^{\text {nd }}$ and July $19^{\text {th }}, 2013$. Data from watered days is in blue while that from reference days is in red. Data in grey is ignored due to uncomparable weather conditions. Similar observations were made at the Belleville site but are not shown. Table 3 summarizes the mean differences observed on reference days for each parameter, height and site over the summers of 2013 and 2014. On the whole, our case stations are warmer and drier on average than their paired control stations at both sites.

Table 3: Average case-control difference on reference days over the summers of 2013 and 2014.

\begin{tabular}{|l|c|c|c|}
\hline Parameter & Height & Louvre & Belleville \\
\hline \multirow{3}{*}{ Air temperature } & $1.5 \mathrm{~m}$ & $+0.26^{\circ} \mathrm{C}$ & $+0.21^{\circ} \mathrm{C}$ \\
\cline { 2 - 4 } & $4 \mathrm{~m}$ & $+0.40^{\circ} \mathrm{C}$ & $+0.31^{\circ} \mathrm{C}$ \\
\hline \multirow{3}{*}{ Relative humidity } & $1.5 \mathrm{~m}$ & $-0.99^{\circ} \%$ & $-0.40^{\circ} \%$ \\
\cline { 2 - 4 } & $4 \mathrm{~m}$ & $-0.81 \%$ & $-0.56^{\circ} \%$ \\
\hline MRT & $1.5 \mathrm{~m}$ & $-0.13^{\circ} \mathrm{C}$ & $+1.35^{\circ} \mathrm{C}$ \\
\hline UTCI & $1.5 \mathrm{~m}$ & $+0.52^{\circ} \mathrm{C}$ & $+0.72^{\circ} \mathrm{C}$ \\
\hline
\end{tabular}




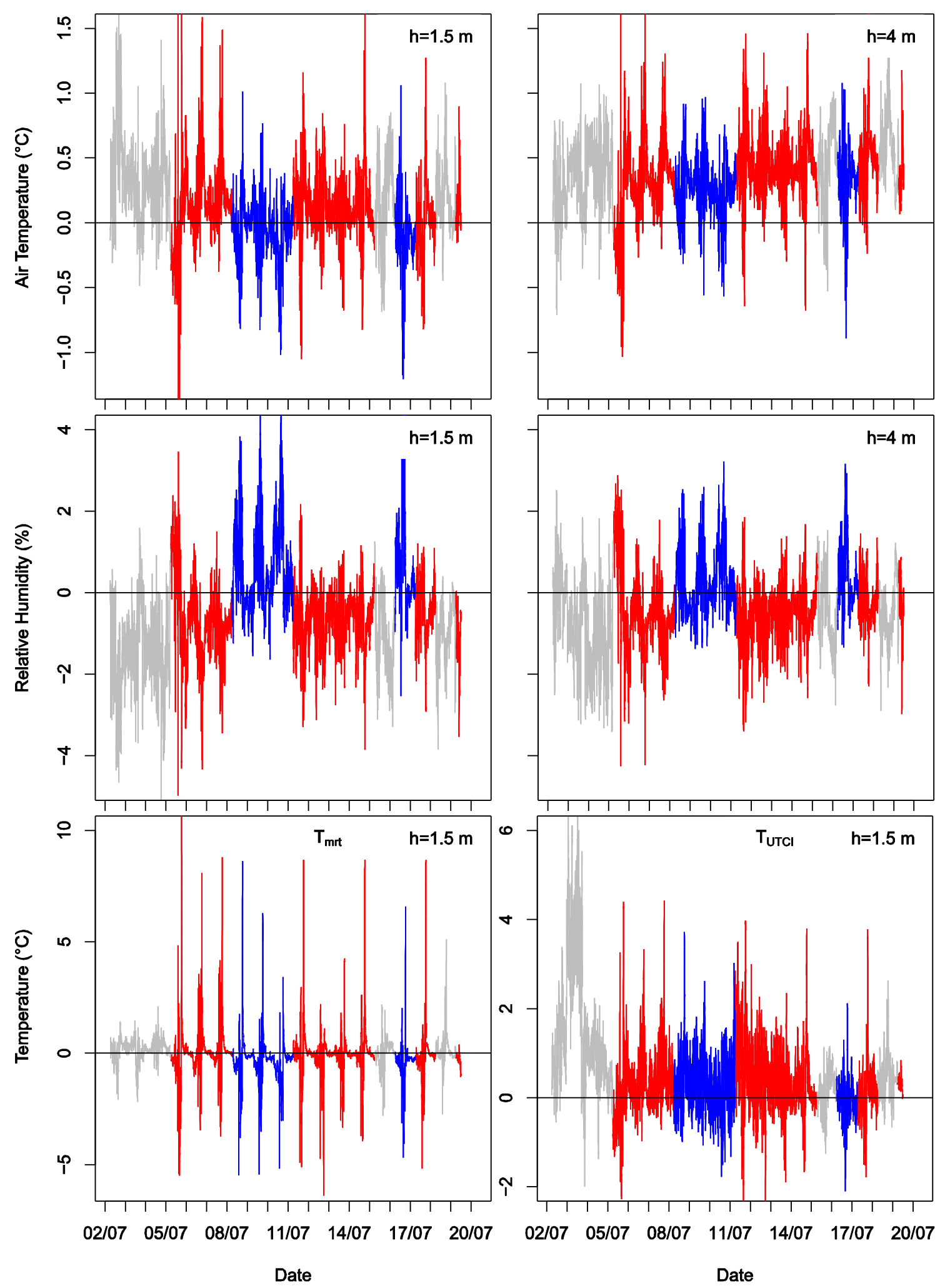

Figure 7: Differences between Louvre case and control stations from July $2^{\text {nd }}$ to $19^{\text {th }}, 2013$ (top to bottom) for $T_{a}$ and $R H$ $1.5 \mathrm{~m}$ (left) and $4 \mathrm{~m}$ (right) a.g.l. and MRT (bottom left) and UTCI (bottom right). Watered days are in blue, reference days are in red. Days with uncomparable weather conditions are in grey. 
We believe this is not an isolated occurrence, but is attributable to the intrinsic complexity of urban environments. As a result, we recommend that field studies of UHI-countermeasures base their analysis on the comparison of reference measurements, made prior to countermeasure implementation, with case periods, made after implementation. By detecting preexisting interstation behavior, normal differences between sites will not be misinterpreted as UHI mitigation effects. While none of the field experiments of pavement-watering we found in the literature proceed in this fashion, it is noteworthy that numerical simulation studies naturally use this method. Indeed, they typically compare the same site in identical conditions, apart from the implementation of the UHI countermeasure. Preexisting conditions are therefore naturally taken into account when the case scenario is analyzed. This strategy can obviously not be transcribed to real-world field trials. We therefore propose an alternative analysis method.

\subsection{Alternative method}

Our method consists of a two-sample t-test of the difference of the interstation profile on watered days compared to reference days. First, the average interstation profile is established for reference and watered days. All reference and watered day observations are grouped by time of day by the minute. For example, each observation of the interstation difference made at 2:07 pm on reference days are grouped together, forming a sample of reference day observations made of 2:07 pm. 1,440 such samples are thus obtained for reference days and as many for watered days. A sample mean and variance can then be calculated for each minute. The series of the minute-by-minute sample means is the sample average interstation difference profile for reference or watered days.

Comparing the obtained mean interstation profiles will only provide a partial answer to the effectiveness of pavement-watering. Indeed, given the statistical nature of meteorological observations, the difference between means on watered and reference days must be tested for statistical significance. This is conducted in the following manner.

To test the difference between the mean value at the $i$-th minute on watered $\left(\mu_{i}^{\text {mex }}\right)$ and reference days $\left(\mu_{i}^{d y}\right)$, a two-sample t-test with a significance level of 0.05 is conducted. The null hypothesis $\left(\mathrm{H}_{0}{ }^{i}\right)$ chosen states that $\mu_{i}$ is greater on watered days than on reference days. The alternative hypothesis $\left(\mathrm{H}_{a}{ }^{i}\right)$ states that $\mu_{i}$ is strictly lower on watered days than on reference days. These hypotheses constitute a one-tailed test. For this analysis, the opposite of $\mathrm{RH}$ and $\mathrm{RH} \mathrm{H}^{4 \mathrm{~m}}$ are used in order to avoid reformulating the hypotheses. Both hypotheses can be summarized as follows, for $\mathrm{i} \in \llbracket 1 ; 1440 \rrbracket$ :

$$
\begin{aligned}
& \mathrm{H}_{0}^{i}: \mu_{i}^{w e t}-\mu_{i}^{d r y} \geq 0 \\
& \mathrm{H}_{a}^{i}: \mu_{i}^{w e t}-\mu_{i}^{d r y}<0
\end{aligned}
$$

If the p-value obtained from the test is lower than the significance level of 0.05 , the null hypothesis is rejected, i.e. the watered day mean is lower than the reference day mean for the considered parameter. However, if the p-value is higher than 0.05 , no statistically significant conclusion can be made.

As a case study application of our method, we use the field measurements from our pavement-watering experiment.

\section{Case study and discussion}

Over the summer of 2013, ten days met the weather conditions required for pavementwatering and 23 additional ones could be used as reference days. Of the ten watered days, July $8^{\text {th }}$ $10^{\text {th }}$ and $16^{\text {th }}$ were the coolest $\left(T_{x} \approx 30^{\circ} \mathrm{C}\right)$, with July $22^{\text {nd }}, 23^{\text {rd }}$ and August $1^{\text {st }}$ and $2^{\text {nd }}$ being the 
warmest $\left(T_{x} \geq 35^{\circ} \mathrm{C}, T_{n} \geq 20^{\circ} \mathrm{C}\right)$. August $23^{\text {rd }}$ and September $5^{\text {th }}$ were also watered and had intermediate temperatures $\left(35^{\circ} \mathrm{C} \geq T_{x} \geq 30^{\circ} \mathrm{C}\right)$. Over this period, the control station on rue du Louvre was vandalized and thus nonoperational from July $19^{\text {th }}$ to August $19^{\text {th }}$ and from September $4^{\text {th }}$ until the end of the summer. Over the same period, the Belleville control station was unpowered from $4 \mathrm{pm}$ on July $22^{\text {nd }}$ until 5 pm on July $25^{\text {th }}$. July $22^{\text {nd }}, 23^{\text {rd }}$ and August $1^{\text {st }}$ and $2^{\text {nd }}$ are therefore excluded from the analysis at Louvre, as are most of July $22^{\text {nd }}$ and $23^{\text {rd }}$ for Belleville.

Although 2014 is France's warmest year since the 1900's as of this writing [31], only two days met the required weather conditions for pavement-watering over the summer of 2014 and five could be used as reference days. July $17^{\text {th }}$ and $18^{\text {th }}$ are the two watered days. August 2014 was particularly cool with a monthly temperature approximately $1.5^{\circ} \mathrm{C}$ colder than average [31]. Although no events caused any of the stations to fail during the summer of 2014, road work occurred at the Louvre watered station from July $29^{\text {th }}$ until the end of the summer.

Over the course of both summers, a total of 12 watered days were observed as well as 28 reference days.

\subsection{Case study results}

Figure 8 and Figure 9 plot the average change detected on watered days compared to reference days (solid blue line) for the Louvre and Belleville sites, respectively. The confidence interval of the difference is illustrated by the two red dashed curves. If the solid curve is in between the dashed curves, the null hypothesis cannot be excluded, i.e. the average effect at that time of day is not statistically significant (stat. sign.). Confidence intervals are widest during periods of instrument insolation.

Watered days exhibit mostly negative changes in $T_{a}, T_{a}^{4 m}$, MRT and UTCI and mostly positive ones for $\mathrm{RH}$ and $\mathrm{RH}^{4 \mathrm{~m}}$. In other words, the environment around the case stations is cooler and more humid, yet overall more comfortable, on watered days than on reference days. Evidently, watering is more effective at Louvre than at Belleville, although maximum effects are comparable.

Taking a closer look, it appears that the greatest effects occur in the afternoon between $2 \mathrm{pm}$ and $7 \mathrm{pm}$, during pavement insolation. Of all considered parameters, $\mathrm{RH}$ is the one that best reflects watering events. Indeed, changes in $\mathrm{RH}$ at Louvre coincide well with watering, which occurs from 6:30 am and 6:30 pm with an interruption between 11:30 am and $2 \mathrm{pm}$. This is not as clear at Belleville, which experienced continuous watering from 7 am to $7 \mathrm{pm}$.

While average effects are apparent, they are not always stat. sign. Table 4 and Table 5 summarize the duration of stat. sign. effects as well as the mean and maximum values reached during that time for air temperature, relative humidity, MRT and UTCI for both sites. In addition to being greater, watering effects are more often stat. sign. at Louvre than at Belleville. Indeed, the duration of stat. sign. effects is at least halved for all parameters at Belleville compared to Louvre.

Looking at the temporal distribution of stat. sign. effects at both sites, it appears that they occur most often at night (after 6 pm), except for RH which is most often stat. sign. during the day. At Louvre, air temperature effects are stat. sign. after 8 am and mostly remain so until 2 am the following day. For RH, stat. sign. effects occur practically as soon as watering starts at 6:30 am and remain so until $4 \mathrm{am}$ on the next day, except during the watering interruption at midday. MRT effects are stat. sign. from 7:30 am until $2 \mathrm{pm}$ and from 6:30 pm until 6 am the next morning, with some sporadic stat. sign. effects between 2 and $6: 30 \mathrm{pm}$. UTCI stat. sign. effects are the most intermittent and mainly occur between 9:30 am and 3 am the next day.

In addition to being smaller, effects at Belleville are much less often stat. sign. than at Louvre. The longest period of continuously stat.sign. effects is observed for MRT and occurs from $9 \mathrm{pm}$ to and $1 \mathrm{am}$, while other parameters are stat.sign. only up to a few hours at a time. 

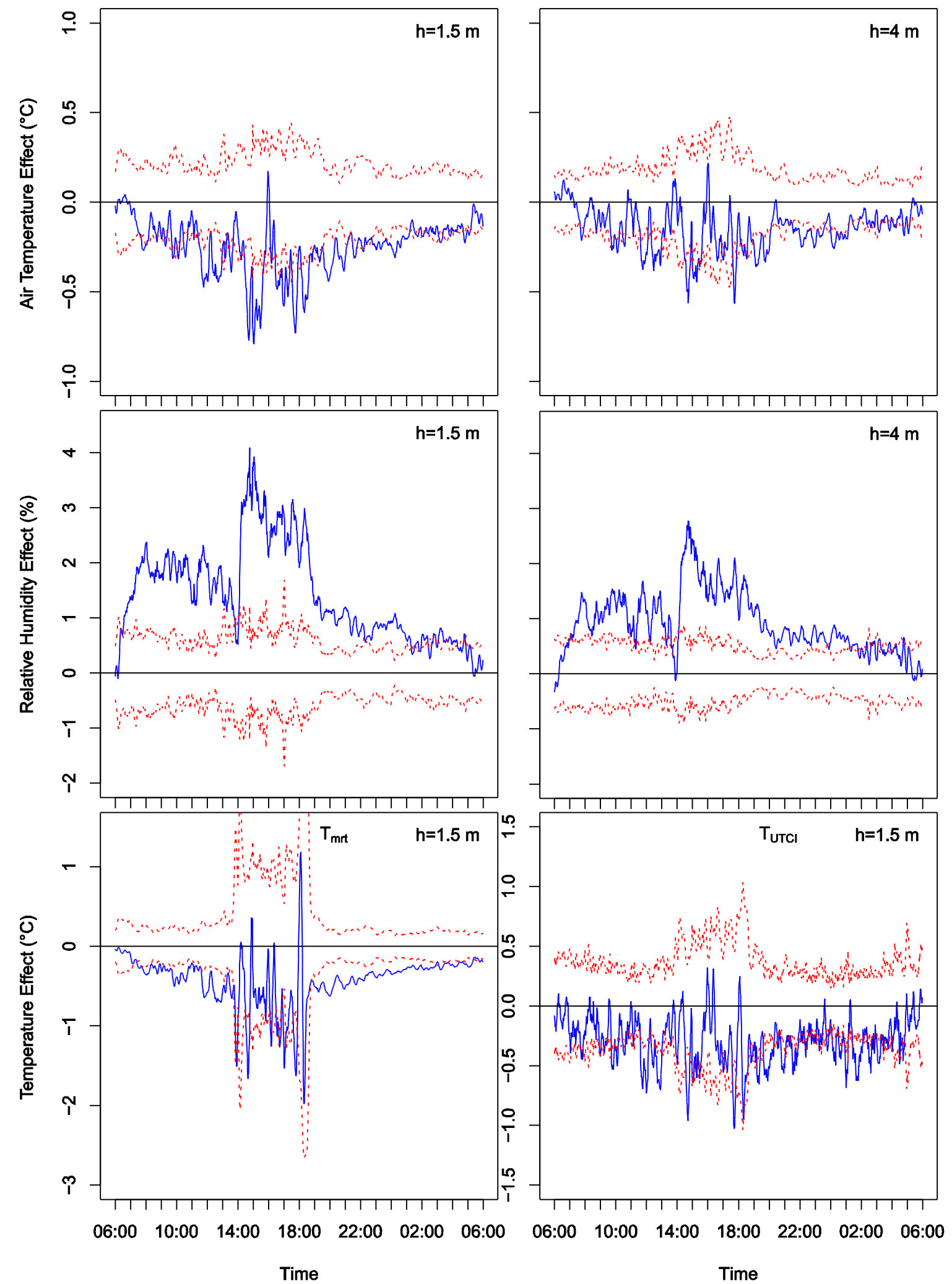

Figure 8: Average watering effect at Louvre (top to bottom) for $T_{a}$ and $R H 1.5 \mathrm{~m}$ (left) and $4 \mathrm{~m}$ (right) a.g.l. and MRT (bottom left) and UTCI (bottom right). Average effects are solid blue, confidence intervals are dashed red. 

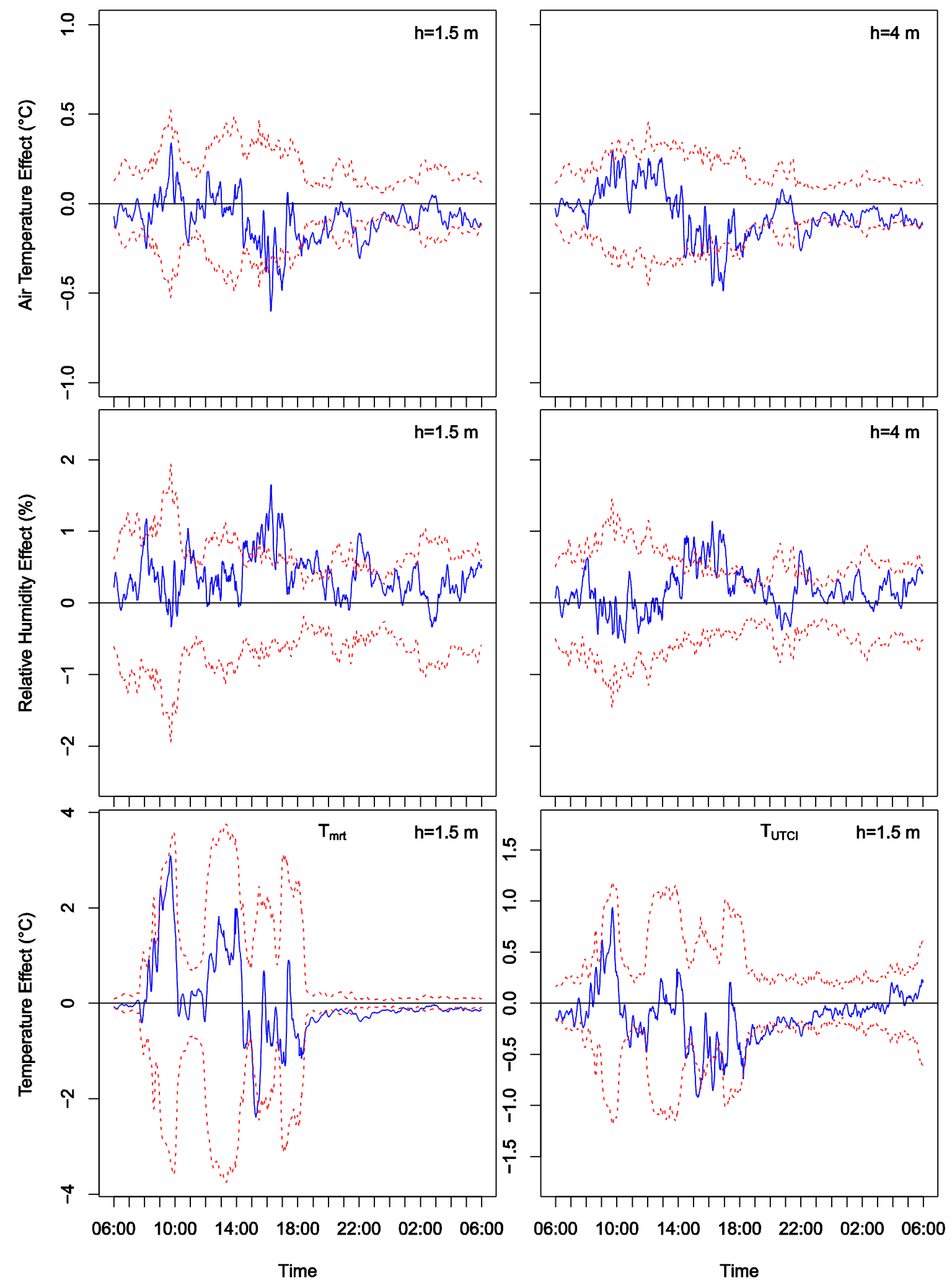

Figure 9: Average watering effect at Belleville (top to bottom) for $T_{a}$ and $\mathrm{RH} 1.5 \mathrm{~m}$ (left) and $4 \mathrm{~m}$ (right) a.g.l. and MRT (bottom left) and UTCI (bottom right). Average effects are solid blue, confidence intervals are dashed red. 
Table 4: Duration, mean and maximum values of stat. sign. effects for Louvre

\begin{tabular}{|l|c|c|c|c|}
\hline Parameter & Height & Duration (hours/day) & Mean effect & Maximum effect \\
\hline \multirow{3}{*}{ Air temperature } & $1.5 \mathrm{~m}$ & 16.7 & $-0.31^{\circ} \mathrm{C}$ & $-0.79^{\circ} \mathrm{C}$ \\
\cline { 2 - 5 } & $4 \mathrm{~m}$ & 12.2 & $-0.22^{\circ} \mathrm{C}$ & $-0.57^{\circ} \mathrm{C}$ \\
\hline \multirow{3}{*}{ Relative humidity } & $1.5 \mathrm{~m}$ & 22.0 & $+1.5 \% \mathrm{RH}$ & $+4.1 \% \mathrm{RH}$ \\
\cline { 2 - 5 } & $4 \mathrm{~m}$ & 20.3 & $+1.1 \% \mathrm{RH}$ & $+2.8 \% \mathrm{RH}$ \\
\hline \multirow{2}{*}{ MRT } & $1.5 \mathrm{~m}$ & 19.5 & $-0.43^{\circ} \mathrm{C}$ & $-1.67^{\circ} \mathrm{C}$ \\
\cline { 1 - 5 } UTCI & & 12.2 & $-0.42^{\circ} \mathrm{C}$ & $-1.03^{\circ} \mathrm{C}$ \\
\hline
\end{tabular}

Table 5: Duration, mean and maximum values of stat. sign. effects for Belleville

\begin{tabular}{|l|c|c|c|c|}
\hline Parameter & Height & Duration (hours/day) & Mean effect & Maximum effect \\
\hline \multirow{3}{*}{ Air temperature } & $1.5 \mathrm{~m}$ & 7.0 & $-0.21^{\circ} \mathrm{C}$ & $-0.60^{\circ} \mathrm{C}$ \\
\cline { 2 - 5 } & $4 \mathrm{~m}$ & 7.0 & $-0.19^{\circ} \mathrm{C}$ & $-0.49^{\circ} \mathrm{C}$ \\
\hline \multirow{3}{*}{ Relative humidity } & $1.5 \mathrm{~m}$ & 7.6 & $+0.7 \% \mathrm{RH}$ & $+1.6 \% \mathrm{RH}$ \\
\cline { 2 - 5 } & $4 \mathrm{~m}$ & 5.2 & $+0.6 \% \mathrm{RH}$ & $+1.1 \% \mathrm{RH}$ \\
\hline \multirow{2}{*}{ MRT } & $1.5 \mathrm{~m}$ & 10.5 & $-0.29^{\circ} \mathrm{C}$ & $-2.39^{\circ} \mathrm{C}$ \\
\hline \multirow{2}{*}{ UTCI } & 6.3 & $-0.39^{\circ} \mathrm{C}$ & $-0.92^{\circ} \mathrm{C}$ \\
\hline
\end{tabular}

Table 6: p-value and average stat. sign. effects at Louvre and Belleville.

\begin{tabular}{|l|c|c|c|c|c|}
\hline \multirow{2}{*}{ Parameter } & \multirow{2}{*}{ Height } & \multicolumn{2}{c|}{ Louvre } & \multicolumn{2}{c|}{ Belleville } \\
\cline { 3 - 7 } & & p-value & Average effect & p-value & Average effect \\
\hline \multirow{3}{*}{ Air temperature } & $1.5 \mathrm{~m}$ & 0.000324 & $-0.25^{\circ} \mathrm{C}$ & 0.134383 & not stat. sign. \\
\cline { 2 - 7 } & $4 \mathrm{~m}$ & 0.00131 & $-0.14^{\circ} \mathrm{C}$ & 0.482932 & not stat. sign. \\
\hline \multirow{2}{*}{ Relative humidity } & $1.5 \mathrm{~m}$ & $6.18 \mathrm{E}-11$ & $+1.46 \% \mathrm{RH}$ & 0.037265 & $+0.29 \% \mathrm{RH}$ \\
\cline { 2 - 7 } & $4 \mathrm{~m}$ & $9.26 \mathrm{E}-09$ & $+0.93 \% \mathrm{RH}$ & 0.298622 & not stat. sign. \\
\hline \multirow{2}{*}{ MRT } & $1.5 \mathrm{~m}$ & 0.000127 & $-0.40^{\circ} \mathrm{C}$ & 0.779618 & not stat. sign. \\
\hline \multirow{2}{*}{ UTCI } & $1.5 \mathrm{~m}$ & 0.000346 & $-0.29^{\circ} \mathrm{C}$ & 0.368533 & not stat. sign. \\
\hline \multirow{2}{*}{ UHI-mitigation } & $1.5 \mathrm{~m}$ & 0.034415 & $-0.14^{\circ} \mathrm{C}$ & 0.131961 & not stat. sign. \\
\cline { 2 - 7 } & $4 \mathrm{~m}$ & 0.015935 & $-0.09^{\circ} \mathrm{C}$ & 0.050258 & not stat. sign. \\
\hline
\end{tabular}

This analysis can also be conducted with daily effects. The same procedure is used but only one iteration is necessary. It is applied to the daily interstation differences on watered and reference days. The average daily effects of pavement-watering are reported in Table 6.

At the Louvre site, the p-value is much lower than 0.05 and even 0.01 for all micro-climatic parameters, i.e. the daily effects observed are highly statistically significant. On the other hand, this is 
not the case at the Belleville site. With a significance level of 0.05 , only $1.5-\mathrm{m} \mathrm{RH}$ shows a significant daily effect of $+0.29 \% \mathrm{RH}$. When UHI-mitigation effects are considered, they are found to be stat. sign. for Louvre only, with $-0.14^{\circ} \mathrm{C}$ and $-0.09^{\circ} \mathrm{C}$ for 1.5 and $4 \mathrm{~m}$ a.g.l., respectively.

This confirms that pavement-watering at Louvre is far more effective than at Belleville, where its daily effects cannot be clearly separated from preexisting background noise.

\subsection{Discussion}

These findings support that pavement-watering is an effective method for limiting maximum daily heat stress, while having stat. sign., although limited, UHI-reducing potential. Maximum effects of up to $0.79^{\circ} \mathrm{C}$ and $0.57^{\circ} \mathrm{C}$ reductions in air temperatures 1.5 - and 4-m a.g.l. were found. Additionally, up to $4.1 \% \mathrm{RH}$ and $2.8 \% \mathrm{RH}$ increases 1.5 - and 4-m a.g.l. were observed, as well as up to $2.39^{\circ} \mathrm{C}$ and $1.0^{\circ} \mathrm{C}$ reductions in MRT and UTCI, respectively. Apart for RH, effects are chiefly stat. sign. at night, although maximum effects occur in the afternoon. Furthermore, effects at Louvre are greater than those observed at Belleville. This is confirmed when daily effects are considered, which are stat. sign. for all parameters at the Louvre site only.

Our findings compare well with those from numerical studies. Good agreement with MétéoFrance \& CSTB is found if the difference in scale is taken into account, i.e. city-wide watering vs. watering a single street portion [14]. Indeed, they report maximum $2 \mathrm{~m}$ air temperature cooling of up to $2^{\circ} \mathrm{C}$ and $\mathrm{UHI}$ mitigation of $0.25^{\circ} \mathrm{C}$ to $0.5^{\circ} \mathrm{C}$. Other simulation work at the district-scale conducted by Wei and $\mathrm{He}$ also agrees well with our findings with maximum reductions in MRT reaching $2.7^{\circ} \mathrm{C}$ in similar situations to our own (see their passage $\mathrm{i}-\mathrm{j}$ ) [32]. Air temperature, relative humidity or thermal comfort effects were not investigated in their analysis. Kubo et al. also conduct a districtscale simulation and find maximum reductions of $0.73^{\circ} \mathrm{C}$ for $1.5 \mathrm{~m}$ air temperature, very similar to our own, and $2.13^{\circ} \mathrm{C}$ at a height of $0.5 \mathrm{~m} \mathrm{[4].}$

Despite the difference in interpretation method, we now present the findings of previous field trials of pavement-watering. In Paris in 2012, Bouvier et al. report up to $0.4^{\circ} \mathrm{C}$ cooling of $2-\mathrm{m}$ air temperature and $4 \%$ increase in relative humidity for a single nighttime watering event [19]. In Lyons, Maillard et al. find a $0.5^{\circ} \mathrm{C}$ reduction in $1.5-\mathrm{m}$ WBGT in the afternoon. In Nagaoka, Japan, Kinouchi \& Kanda report reductions of up to $1^{\circ} \mathrm{C}$ in $1-\mathrm{m}$ air temperature and $4^{\circ} \mathrm{C}$ in $1-\mathrm{m}$ globe temperature as well as a $4 \%$ increase in relative humidity [15]. Average effects are in the order of $0.5^{\circ} \mathrm{C}$ for air temperature, $2^{\circ} \mathrm{C}$ for globe temperature and $3 \%$ for relative humidity. Also in Nagaoka, Takahasi et al. investigate $0.9-\mathrm{m}$ air temperature cooling of up to $2^{\circ} \mathrm{C}$ in the morning and $4{ }^{\circ} \mathrm{C}$ in the afternoon [17]. Finally, in Tokyo Yamagata et al. find up to $3^{\circ} \mathrm{C}$ and $2^{\circ} \mathrm{C}$ reductions in $0.5-\mathrm{m}$ air temperature and WBGT, respectively [18].

It is difficult to compare these results with our own given that they are obtained by directly comparing measurements at watered and control stations, without taking preexisting interstation differences into account. Indeed, natural background differences between chosen case and control sites may cause over- or underestimation of reported cooling effects.

More generally-speaking, the observed results agree well with expectations based on the physical phenomena behind pavement-watering and observations made in our previous studies of thermal effects [21], [22]. Indeed, micro-climatic effects are highest during insolation, as were pavement surface temperature and heat flux reductions. This is especially true for RH, providing very good correspondence with watering cycles and the evaporation rates estimated in the morning and afternoon [21], [22]. This good agreement significantly strengthens our microclimatic findings which can thus be backed by thermal observations and predicted physical phenomena.

The difference between Louvre and Belleville effects is likely best explained by the difference in watering strategies between both sites. Indeed, the greater the watered surface, the more total 
sensible heat flow and total upwards radiation are reduced. Since $100 \%$ of the street surface is watered at Louvre compared to $33 \%$ watering at Belleville, the difference between sites is unsurprising. In addition, watering at Belleville only targeted the pavement, but not the sidewalk where the weather stations were placed and where pedestrians are likely to be. Belleville stations are therefore further away from the watered area than they are at Louvre. Finally, the differences in street orientation also play a role, since pavement cooling was found to be greatest during insolation in our previous work [21], [22]. Differences in insolation patterns and durations will therefore alter the effects of pavement-watering. The combination of these effects is expected to amplify the differences between sites. We therefore conclude that watering one third of the street is much less effective than watering all of it, and should at the very least attempt to target the area to which pedestrians are most exposed, i.e. the sidewalk.

One limitation of the analysis of Louvre effects is the absence of the warmest days observed over both summers, i.e. August $1^{\text {st }}$ and $2^{\text {nd }}, 2013$. In addition, due to the proximity of these stations, the influence of the watered area on the control area cannot be excluded. These limitations can be overcome by analyzing the difference of the Louvre case station with the Belleville control. The first two columns of Nonetheless, the cage inevitably causes partial shading of the globe thermometer during insolation and shields the instrument from environmental radiation. MRT is therefore likely underestimated in the day. At night, competing effects are at work. On the one hand, the cage partially obstructs the low temperature sky radiation, which will tend to cause an overestimation of MRT. On the other hand, the higher temperature ground and wall radiation is also inhibited by the cage, which will tend to cause an underestimation of MRT. It is uncertain which of these tendencies is dominant at night.

While a dedicated study of the influence of the cage on the measured parameters is necessary to confirm this preliminary analysis, cage effects are expected to mainly affect the estimation of MRT from globe temperature.

Table 7 provide the p-value and average effects for daily observations determined in this manner, while the remaining columns and Figure 10 summarize the effects found with the full measurement data series.

Detected maximum effects are increased for all parameters, but only marginally for $1.5-\mathrm{m}$ air temperature and relative humidity. This supports the hypothesis that the watered area influences dry area measurements. However, the statistical significance of the detected effects deteriorates, particularly for air temperature and UTCI. This can be attributed to increased differences in insolation patterns within the new station pair as compared to the initial one. In terms of UHImitigation, only effects at $4 \mathrm{~m}$ a.g.l. are stat. sign. and reach $-0.22^{\circ} \mathrm{C}$.

This example provides interesting feedback on the potential and the limits of the proposed method. While strictly paired stations benefit from reduced data variance and therefore have higher accuracy, strict site selection criteria filter out large numbers of candidate sites for experimentation. This example demonstrates that the analysis can be successfully conducted in much less favorable conditions if need be. Indeed, despite significantly different street orientations, several kilometers between paired stations and different environments, the method successfully provides comparable values of daily and maximum watering effects. The tradeoff for this added flexibility however is the widened confidence intervals, resulting from increased signal noise, which reduces the statistical significance of the detected effects. In our example, UTCI and UHI-mitigation $1.5 \mathrm{~m}$ a.g.l. effects are not stat. sign. for this reason.

Confidence intervals are greatest during periods of instrument insolation. Using aspirated instrument shields should help address this issue for air temperature and humidity measurements by eliminating the influence of insolation differences between stations on these parameters. Unfortunately, no equivalent solution exists for the globe thermometer. 
Additional limits more specific to our experimental setup can be identified. Among these, the influence of the cage used to protect the datalogger and instruments installed $1.5 \mathrm{~m}$ a.g.l. should be noted, though instruments installed outside of the cage are not expected to be affected.

The cage is designed to limit its influence on the meteorological parameters measured within it as much as possible. Indeed, the cage mesh is $4 \mathrm{~cm}$ by $4 \mathrm{~cm}$, resulting in a highly permeable design. In addition, it is entirely painted white to reduce atmospheric heating which may result from its exposure to direct insolation. Therefore, the influence of the cage on air temperature and humidity is expected to be negligible. 

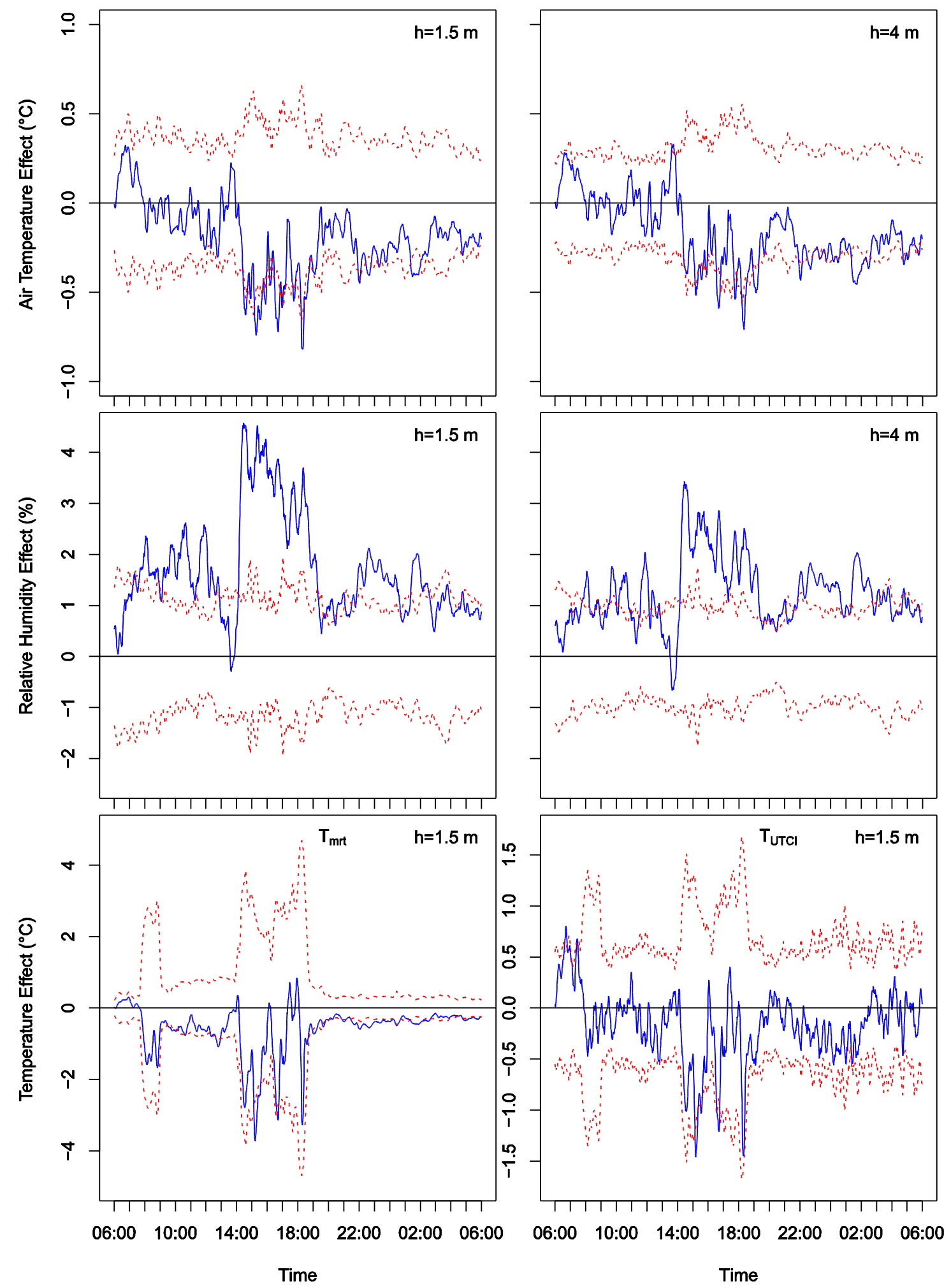

Figure 10: Average watering effect at Louvre detected using the Belleville control stations (top to bottom) for $T_{a}$ and RH $1.5 \mathrm{~m}$ (left) and $4 \mathrm{~m}$ (right) a.g.l. and MRT (bottom left) and UTCI (bottom right). Average effects are solid blue, confidence intervals are dashed red. 
Nonetheless, the cage inevitably causes partial shading of the globe thermometer during insolation and shields the instrument from environmental radiation. MRT is therefore likely underestimated in the day. At night, competing effects are at work. On the one hand, the cage partially obstructs the low temperature sky radiation, which will tend to cause an overestimation of MRT. On the other hand, the higher temperature ground and wall radiation is also inhibited by the cage, which will tend to cause an underestimation of MRT. It is uncertain which of these tendencies is dominant at night.

While a dedicated study of the influence of the cage on the measured parameters is necessary to confirm this preliminary analysis, cage effects are expected to mainly affect the estimation of MRT from globe temperature.

Table 7: Daily p-value, daily average, duration, mean and maximum values of stat. sign. effects for Louvre, using the Belleville control station

\begin{tabular}{|c|c|c|c|c|c|c|}
\hline Parameter & Height & $\begin{array}{c}\text { Daily p- } \\
\text { value }\end{array}$ & Daily effect & $\begin{array}{c}\text { Duration } \\
\text { (hours/day) }\end{array}$ & $\begin{array}{l}\text { Mean } \\
\text { effect }\end{array}$ & $\begin{array}{c}\text { Maximum } \\
\text { effect }\end{array}$ \\
\hline \multirow{2}{*}{$\begin{array}{l}\text { Air } \\
\text { temperature }\end{array}$} & $1.5 \mathrm{~m}$ & 0.001035 & $-0.24^{\circ} \mathrm{C}$ & 6.2 & $-0.45^{\circ} \mathrm{C}$ & $-0.82^{\circ} \mathrm{C}$ \\
\hline & $4 \mathrm{~m}$ & 0.020352 & $-0.17^{\circ} \mathrm{C}$ & 7.9 & $-0.35^{\circ} \mathrm{C}$ & $-0.71^{\circ} \mathrm{C}$ \\
\hline \multirow{2}{*}{$\begin{array}{l}\text { Relative } \\
\text { humidity }\end{array}$} & $1.5 \mathrm{~m}$ & 6.92E-07 & $+1.87 \% \mathrm{RH}$ & 18.0 & $+2.0 \% \mathrm{RH}$ & $+4.6 \% \mathrm{RH}$ \\
\hline & $4 \mathrm{~m}$ & $1.45 \mathrm{E}-07$ & $+1.33 \% \mathrm{RH}$ & 18.2 & $+1.5 \% \mathrm{RH}$ & $+3.4 \% \mathrm{RH}$ \\
\hline MRT & $1.5 \mathrm{~m}$ & 0.000813 & $-0.70^{\circ} \mathrm{C}$ & 11.1 & $-0.60^{\circ} \mathrm{C}$ & $-3.73^{\circ} \mathrm{C}$ \\
\hline UTCI & $1.5 \mathrm{~m}$ & 0.150749 & not stat. sign. & 1.3 & $-0.95^{\circ} \mathrm{C}$ & $-1.46^{\circ} \mathrm{C}$ \\
\hline \multirow{2}{*}{$\begin{array}{l}\text { UHI- } \\
\text { mitigation }\end{array}$} & $1.5 \mathrm{~m}$ & 0.104996 & not stat. sign. & & & \\
\hline & $4 \mathrm{~m}$ & 0.042564 & $-0.22^{\circ} \mathrm{C}$ & & & \\
\hline
\end{tabular}

\section{Conclusion}

A statistical analysis method was proposed to reliably determine the real-world micro-climatic effects of UHI-countermeasures in cities. The method consists of a two-sample t-test of the difference between mean interstation differences observed on watered and reference days. Preexisting differences between experimental and control stations are thus taken into account, previously ignored by the dominant method of directly comparing measurements between them.

A pavement-watering experiment conducted over the summers of 2013 and 2014 at two sites in Paris, France was used to test the proposed methodology. Both sites had a canyon aspect ratio approximately equal to one, while the Louvre site has an approximate N-S street orientation and the Belleville site an approximate E-W orientation. Watering was conducted over the full width of the Louvre site from 6:30 am to 11:30 am and from $2 \mathrm{pm}$ to $6: 30 \mathrm{pm}$, while only a third of Belleville was watered from 7 am to $7 \mathrm{pm}$ without interruption.

The method was successfully tested with data collected at well-paired stations, but also with stations paired between sites, despite their large differences. Results show that pavement-watering is an effective means of reducing maximum heat stress, while also having UHI-mitigation effects. Indeed, we found that conditions at the case stations on watered days were cooler and more humid than reference days in varying intensity over the course of the day. However, these effects weren't always statistically significant. 
Relative humidity, followed by MRT, air temperature and UTCI, was most often affected in a statistically significant manner by pavement-watering. Furthermore, significant effects occurred most often at night for air, mean radiant and UTCI-equivalent temperatures, while they occurred most often during the day for relative humidity. However, maximum significant effects occurred during the day for all parameters, when conditions are hottest and driest. Maximum reductions reported reached $0.79^{\circ} \mathrm{C}$ and $0.57^{\circ} \mathrm{C}$ for air temperature 1.5 - and $4-\mathrm{m}$ a.g.l., $1.67^{\circ} \mathrm{C}$ for $\mathrm{MRT}$ and $1.03^{\circ} \mathrm{C}$ for UTCI-equivalent temperature. Maximum increases in relative humidity reached $4.1 \%$ RH $1.5 \mathrm{~m}$ a.g.l. and $2.8 \%$ RH 4-m a.g.l.

Daily-averaged data was also considered and revealed that average watering effects were statistically significant in the case of $100 \%$ watering at Louvre, but not so with one-third watering at Belleville. Average effects at Louvre reached $-0.25^{\circ} \mathrm{C}$ and $-0.14^{\circ} \mathrm{C}$ for 1.5 - and $4-\mathrm{m}$ air temperature, $+1.5 \% \mathrm{RH}$ and $+0.9 \% \mathrm{RH}$ for 1.5 - and $4-\mathrm{m}$ relative humidity, $-0.40^{\circ} \mathrm{C}$ for MRT and $-0.29^{\circ} \mathrm{C}$ for UTCI equivalent temperature. UHI-mitigation effects were investigated using air temperatures 1.5 and $4 \mathrm{~m}$ a.g.l. averaged between 3 am and $6 \mathrm{am}$. These effects ranged from $-0.09^{\circ} \mathrm{C}$ to $-0.22^{\circ} \mathrm{C}$.

The methodology presented here was applied to pavement-watering which has the advantage over other more permanent UHI countermeasures of being immediately reversible. Indeed, when watering is not taking place, the study sites naturally revert to their preexisting dry state. This allowed us to record data to build average interstation difference profiles for both watered and reference days simultaneously. The two data series could then be compared to determine the effects of pavementwatering.

In the case of long-lasting countermeasures, it is not possible to record reference data once the measure has been implemented. It is therefore necessary to start monitoring test sites sufficiently ahead of time to allow for enough reference data to be recorded. This data is crucial and must provide a representative image of the preexisting interstation differences. Since weather conditions are random, there is no telling how long this reference period must last and it will depend on the weather conditions of interest. We estimate that it may range from several weeks up to a few years. In our case, heat-wave conditions were the focus point. While we were fortunate that the summer of 2013 exhibited such a large number of relevant days and allowed us to conduct our analysis, the summer of 2014, with only two watered and five reference days, would not have provided sufficient data to conduct a reliable analysis.

The length of the investigation period is one of the limits of the method. Requiring data series spanning over several months or years implies that the only change expected is the implementation of the UHI countermeasure. However, urban environments are ever changing and preexisting conditions determined over a certain period may become rapidly obsolete in certain areas. This adds additional burden to the site selection criteria which must also be relatively stable over the full investigation period. Luckily, it was found that site selection criteria can be made more flexible in exchange for a loss in analysis precision by using station pairs whose urban configurations are not as identical as the ones selected here.

The strength of our findings on the effects of pavement-watering will increase as more data is collected. Paths for improvement include the use of high precision instruments calibrated against each other on a regular basis in a laboratory-controlled chamber and the use of aspirated solar shelters to eliminate the influence of insolation on air temperature and humidity measurements. Furthermore, a study of the influence of the measurement cage on weather instruments must conducted.

Future studies applying our methodology to other sites with other UHI countermeasures will provide additional feedback as to its relevance and applicability in the field. Further ways of improvement may also arise. Unfortunately, since the investigation period must be long, so will the time before significant feedback can be gathered. 


\section{Acknowledgements}

The authors acknowledge the support of Météo-France and APUR (Parisian urban planning agency) as well as the Green Spaces and Environment, Roads and Traffic and the Waste and Water Divisions of the City of Paris during the preparation phase of this experiment.

Funding for this experiment was provided for by the Water and Sanitation Department of the City of Paris.

\section{Nomenclature}

\begin{tabular}{|c|c|c|}
\hline Symbol & Quantity & [SI unit] \\
\hline a.g.l. & Above ground level & \\
\hline$B M I_{M a x}$ & Maximum biometeorological index & {$\left[{ }^{\circ} \mathrm{C}\right]$} \\
\hline$B M I_{M i n}$ & Minimum biometeorological index & {$\left[{ }^{\circ} \mathrm{C}\right]$} \\
\hline$c$ & Water specific heat & {$[\mathrm{J} / \mathrm{kg} \cdot \mathrm{K}]$} \\
\hline$E$ & Evaporation rate & {$[\mathrm{g} / \mathrm{s}]$} \\
\hline$G$ & Pavement heat flux density & {$\left[\mathrm{W} / \mathrm{m}^{2}\right]$} \\
\hline $\mathrm{H} / \mathrm{W}$ & Urban canyon aspect ratio & {$[-]$} \\
\hline$H$ & Sensible heat flux density & {$\left[\mathrm{W} / \mathrm{m}^{2}\right]$} \\
\hline$l$ & Latent heat of vaporization & {$[\mathrm{J} / \mathrm{kg}]$} \\
\hline$L_{\text {down }}$ & Downwards longwave radiation & {$\left[\mathrm{W} / \mathrm{m}^{2}\right]$} \\
\hline$L_{u p}$ & Upwards longwave radiation & {$\left[\mathrm{W} / \mathrm{m}^{2}\right]$} \\
\hline$\mu$ & Average parameter value & \\
\hline \multirow[t]{3}{*}{ MRT } & Mean radiant temperature & {$\left[{ }^{\circ} \mathrm{C}\right]$} \\
\hline & Pavement-watering cooling flux density & {$\left[\mathrm{W} / \mathrm{m}^{2}\right]$} \\
\hline & Water density & {$\left[\mathrm{kg} / \mathrm{m}^{3}\right]$} \\
\hline $\mathrm{RH}$ & $1.5-\mathrm{m}$ relative humidity & {$[-]$} \\
\hline$R H^{4 m}$ & 4-m relative humidity & {$[-]$} \\
\hline $\mathrm{R}_{n}$ & Net downwards radiation & {$\left[\mathrm{W} / \mathrm{m}^{2}\right]$} \\
\hline$S$ & Downwards shortwave radiation & {$\left[\mathrm{W} / \mathrm{m}^{2}\right]$} \\
\hline$S_{r e f}$ & Upwards reflected shortwave radiation & {$\left[\mathrm{W} / \mathrm{m}^{2}\right]$} \\
\hline stat. sign. & statistically significant & {$[-]$} \\
\hline$T_{a}$ & 1.5-m air temperature & {$\left[{ }^{\circ} \mathrm{C}\right]$} \\
\hline$T_{a}^{4 m}$ & 4-m air temperature & {$\left[{ }^{\circ} \mathrm{C}\right]$} \\
\hline$T_{g}$ & Globe temperature & {$\left[{ }^{\circ} \mathrm{C}\right]$} \\
\hline$T_{x}^{g}$ & Maximum air temperature & {$\left[{ }^{\circ} \mathrm{C}\right]$} \\
\hline$T_{n}^{n}$ & Minimum air temperature & {$\left[{ }^{\circ} \mathrm{C}\right]$} \\
\hline$T_{S}$ & Pavement surface temperature & {$\left[{ }^{\circ} \mathrm{C}\right]$} \\
\hline$T_{W}$ & Sprinkled water temperature & {$\left[{ }^{\circ} \mathrm{C}\right]$} \\
\hline$t_{0}$ & Water cycle period & {$[\mathrm{s}]$} \\
\hline UHI & Urban heat island & \\
\hline UTCI & Universal Thermal Climate Index & {$\left[{ }^{\circ} \mathrm{C}\right]$} \\
\hline$v$ & Wind speed & {$[\mathrm{m} / \mathrm{s}]$} \\
\hline$V_{s}$ & Sprinkled water volume & {$\left[\mathrm{L} / \mathrm{m}^{2}\right]$} \\
\hline WBGT & Wet-bulb globe temperature & {$\left[{ }^{\circ} \mathrm{C}\right]$} \\
\hline
\end{tabular}

\section{References}

[1] California Energy Commission, Efficiency Standards for Residential and Nonresidential Buildings, no. 
May 2012. 2010, p. 169.

[2] H. Li, J. T. Harvey, T. J. Holland, and M. Kayhanian, "Corrigendum: The use of reflective and permeable pavements as a potential practice for heat island mitigation and stormwater management," Environ. Res. Lett., vol. 8, no. 4, p. 049501, Dec. 2013.

[3] T. Karlessi, M. Santamouris, A. Synnefa, D. Assimakopoulos, P. Didaskalopoulos, and K. Apostolakis, "Development and testing of PCM doped cool colored coatings to mitigate urban heat island and cool buildings," Build. Environ., vol. 46, no. 3, pp. 570-576, Mar. 2011.

[4] K. Kubo, H. Kido, and M. Ito, "Study on pavement technologies to mitigate the heat island effect and their effectiveness," in 10th International Conference on Asphalt Pavements, 2006, pp. 223-232.

[5] R. Levinson, H. Akbari, and J. C. Reilly, "Cooler tile-roofed buildings with near-infraredreflective non-white coatings," Build. Environ., vol. 42, no. 7, pp. 2591-2605, Jul. 2007.

[6] H. Takebayashi and M. Moriyama, "Surface heat budget on green roof and high reflection roof for mitigation of urban heat island," Build. Environ., vol. 42, no. 8, pp. 2971-2979, Aug. 2007.

[7] H. Takebayashi and M. Moriyama, "Study on the urban heat island mitigation effect achieved by converting to grass-covered parking," Sol. Energy, vol. 83, no. 8, pp. 1211-1223, Aug. 2009.

[8] E. Jauregui, "Influence of a large urban park on temperature and convective precipitation in a tropical city," Energy Build., vol. 15, no. 3-4, pp. 457-463, Jan. 1990.

[9] V. T. Ca, T. Asaeda, and E. M. Abu, "Reductions in air conditioning energy caused by a nearby park," Energy Build., vol. 29, no. 1, pp. 83-92, Dec. 1998.

[10] M. Santamouris, "Using cool pavements as a mitigation strategy to fight urban heat island-A review of the actual developments," Renew. Sustain. Energy Rev., vol. 26, pp. 224-240, Oct. 2013.

[11] D. E. Bowler, L. Buyung-Ali, T. M. Knight, and A. S. Pullin, "Urban greening to cool towns and cities: A systematic review of the empirical evidence," Landsc. Urban Plan., vol. 97, no. 3, pp. 147-155, Sep. 2010.

[12] H. Akbari, M. Pomerantz, and H. Taha, "Cool surfaces and shade trees to reduce energy use and improve air quality in urban areas," Sol. Energy, vol. 70, no. 3, pp. 295-310, Jan. 2001.

[13] T. Nakayama, S. Hashimoto, and H. Hamano, "Multiscaled analysis of hydrothermal dynamics in Japanese megalopolis by using integrated approach," Hydrol. Process., vol. 26, no. 16, pp. 2431-2444, Jul. 2012.

[14] Météo France and CSTB, "EPICEA Project - Final Report," Paris, France (in French), 2012.

[15] T. Kinouchi and M. Kanda, "An Observation on the Climatic Effect of Watering on Paved Roads," J. Hydrosci. Hydraul. Eng., vol. 15, no. 1, pp. 55-64, 1997.

[16] T. Kinouchi and M. Kanda, "Cooling Effect of Watering on Paved Road and Retention in Porous Pavement," in Second Symposium on Urban Environment, 1998, pp. 255-258.

[17] R. Takahashi, A. Asakura, K. Koike, S. Himeno, and S. Fujita, "Using Snow Melting Pipes to Verify the Water Sprinkling's Effect over a Wide Area,” in NOV ATECH 2010, 2010, p. 10.

[18] H. Yamagata, M. Nasu, M. Yoshizawa, A. Miyamoto, and M. Minamiyama, "Heat island mitigation using water retentive pavement sprinkled with reclaimed wastewater," Water Sci. Technol. a J. Int. Assoc. Water Pollut. Res., vol. 57, no. 5, pp. 763-771, Jan. 2008.

[19] M. Bouvier, A. Brunner, and F. Aimé, "Nighttime watering streets and induced effects on the surrounding refreshment in case of hot weather. The city of Paris experimentations," Tech. Sci. Méthodes, no. 12, pp. 43-55 (in French), 2013.

[20] P. Maillard, F. David, M. Dechesne, J.-B. Bailly, and E. Lesueur, "Characterization of the Urban Heat Island and evaluation of a road humidification mitigation solution in the district of La Part-Dieu, Lyon (France)," Tech. Sci. Méthodes, no. 6, pp. 23-35 (in French), 2014. 
[21] M. Hendel, M. Colombert, Y. Diab, and L. Royon, "An analysis of pavement heat flux to optimize the water efficiency of a pavement-watering method," Appl. Therm. Eng., vol. 78, pp. 658-669, 2015.

[22] M. Hendel, M. Colombert, Y. Diab, and L. Royon, "Improving a pavement-watering method on the basis of pavement surface temperature measurements," Urban Clim., vol. 10, no. December, pp. 189-200, Dec. 2014.

[23] M. Hendel and L. Royon, "The effect of pavement-watering on subsurface pavement temperatures," Urban Clim., 2015.

[24] ASHRAE, ASHRAE Fundamentals Handbook. 2001, SI Edition. American Society of Heating, Refrigerating, and Air-Conditioning Engineers, 2001.

[25] "ISO16622:2002 Meteorology - Sonic Anemometers/thermometers - Acceptance Test Methods for Mean Wind Speeds.” .

[26] "IEC 60751:2008 - Industrial platinum resistance thermometers and platinum temperature sensors." .

[27] K. Blazejczyk, P. Bröde, D. Fiala, G. Havenith, I. Holmér, G. Jendritzky, B. Kampmann, and A. Kunert, "Principles of the new Universal Thermal Climate Index (UTCI) and its Application to Bioclimatic Research in European Scale," Misc. Geogr., vol. 14, pp. 91-102, 2010.

[28] "Universal Thermal Climate Index - Documents." [Online]. Available: http://www.utci.org/utci_doku.php. [Accessed: 22-Jun-2015].

[29] J. Lekner and M. C. Dorf, "Why some things are darker when wet.," Appl. Opt., vol. 27, no. 7, pp. 1278-80, Apr. 1988.

[30] F. Pasquill, "The estimation of the dispersion of windborne material," Meteorol. Mag., vol. 90, no. 1063, pp. 33-49, 1961.

[31] Météo France, "2014 : année record pour les températures en France et en Europe," 2015. [Online]. Available: http:/ /www.meteofrance.fr/actualites?articleId=20344090. [Accessed: 27Nov-2014].

[32] J. Wei and J. He, "Numerical simulation for analyzing the thermal improving effect of evaporative cooling urban surfaces on the urban built environment," Appl. Therm. Eng., vol. 51, no. 1-2, pp. 144-154, Mar. 2013. 